\title{
FIRST RECORD OF BROAD-SNOUTED SEVEN-GILLED SHARK FROM CANANÉIA, COAST OF BRAZIL
}

(Received in 8/5/1969)

\author{
Victor SADOWSKY
}

Instituto Oceanográfico da Universidade de São Paulo

A young female (T.L. $753 \mathrm{~mm}$ ) of the broadsnouted seven-gilled shark, Notorynchus pectorosus (Garman, 1913), was caught on June, 1968, in a gill net at depth of $6 \mathrm{~m}$ off Cananéia $\left(25^{\circ} \mathrm{S}, 47^{\circ} 52^{\prime} \mathrm{W}\right)$. The bottom water temperature at the the time of capture was $20.6^{\circ} \mathrm{C}$.

Together with it some other sharks, Rhizoprionodon porosus Poey, Rh. lalandei Val., and Carcharhi nus porosus (Ranzanı), were captured, all adult males.

The species Notorynchus pectorosus is distributed in the Pacific and Indian Oceans, as well as in the southern Atlantic, off Argentina (LAHILle, 1928) and South Africa (Sмiтh, 1953), while it was not recorded from other parts of the Atlantic (Bigelow \& Schroeder, 1948; Manday, 1968; Tortonese, 1956; Cadenat, 1950; and others), and not from Brazil (Fowler, 1942) nor from the region of Cananéia (SADOWSKY, 1967).

The specific characters of the shark from Cananéia correspond perfectly to those of Garman's des. cription (1913, p. 20-21); however, they show some differences concerning the morphological proportions compared with the description of the same species given by LAHILle (1928) and CHEN (1963) under the name of Heptranchias pectorosus Garman, 1884. These differences might be due to allometric growth, as the examined specimens were of quite different sizes: that from Cananéia was $753 \mathrm{~mm}$ long, those of Chen and of LAHiLle, $1930 \mathrm{~mm}$ and $2070 \mathrm{~mm}$, respectively.

As the nomenclature of the genus to which the species belongs is doubtful, I adopt the one recently used by Garrick \& Schultz (1963).

Publ. n. 277 do Inst. Ocean. da USP.
As the scientific literature does not yet contain detailed data referring to the morphology of young specimens of the species, I give the measurements of the present material (Table I) according to the indications of Bigelow \& Schroeder (1948) and others (Tortonese, 1956; SAdowsky, 1968), and add a short description of the observed peculiarities.

In fresh state the color of the back of $N$. pectorosus (Fig. 1) was greyish violet, the ventral side greyish white (lead or ice). During preservation in formol $10 \%$ the color of the back changed to yellowish pink, while the ventral side retained its color. The dark spots scattered irregularly on the dorsal side are roundish; their diameter varies from 2-18 $\mathrm{mm}$. On the central part of the head, a little in front of the spiracula, there are two small endolymphatic pores, with an interspace of $4.5 \mathrm{~mm}$. The upper edge of the caudal fin is protected by 3 or 4 series of enlarged dermal denticles. The same denticles, only a little less stout, occur also on the edges of the anterior border of all the other fins.

The dental formula is: (9)-6-1-1-1-6-(8) for the upper teeth, and: (7)-6-1-6-(6) for the lower teeth. The numbers in brackets indicate the series of very small teeth which form a plate of about $12 \mathrm{~mm}$ in length. In the upper jaw there is a central tooth. The central series and the two para-central ones each have 2 typical funcional teeth, the other series, only one. The lower median tooth has a median notch and 3 cusps on either side.

The specimen is preserved in the collection of the Oceanographic Station at Cananéia.

For the translation of the manuscript I thank Mrs. Eveline Marcus. 
Total length

Distance from snout tip to:

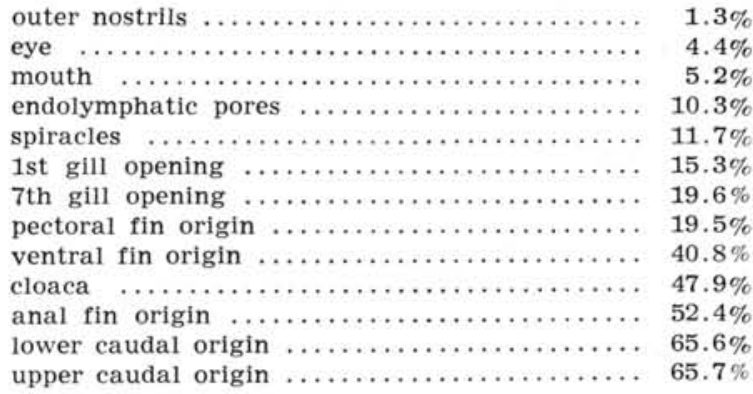

Distance between bases of fins:

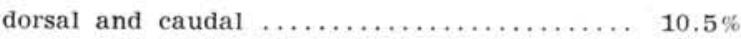

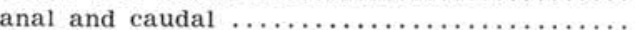

Distance from origin to origin:

pectoral and ventral fin

ventral and anal fins

Trunk at origin of pectoral:

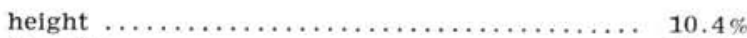

breadth $10.6 \%$

Trunk at ventral origin, breadth $\ldots \ldots \ldots \ldots \ldots .6 .2 \%$

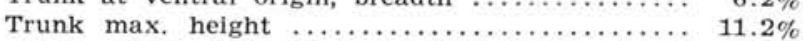

Eye:

horizontal diameter $\ldots \ldots \ldots \ldots \ldots \ldots \ldots \ldots$

vertical diameter ................... $1.0 \%$

Mouth:

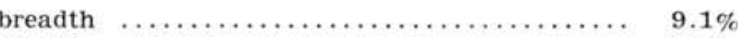

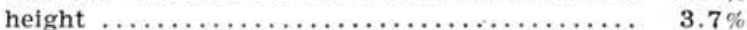

Internarial space, width .................. $4.2 \%$

Distance interorbital .................. $7.7 \%$

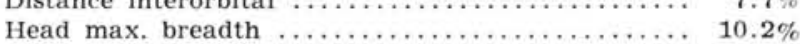

Ventral fin tip to anal origin .............. $3.7 \%$
Labial fold:

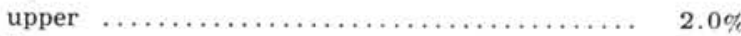

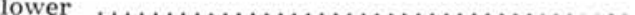

Gill openings length:

\begin{tabular}{|c|c|}
\hline nd & , \\
\hline $\mathrm{rd}$ & $\ldots \ldots \ldots \ldots \ldots \ldots$ \\
\hline th & 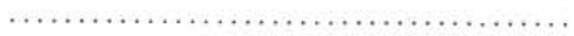 \\
\hline th & $\ldots \ldots \ldots \ldots \ldots \ldots \ldots \ldots \ldots \ldots \ldots$ \\
\hline & $\ldots \ldots, \ldots, \ldots$ \\
\hline & $\ldots \ldots \ldots \ldots \ldots \ldots$ \\
\hline
\end{tabular}

Distance between 1st and 7th gill openings:

upper corners $\ldots \ldots \ldots \ldots \ldots \ldots \ldots \ldots \ldots \ldots, 4.7 \%$

lower corners ..................... $5.0 \%$

Spiracle length ............ $0.4 \%$

Dorsal fin:

height ..... $3.8 \%$

length of base ............................... $6.9 \%$

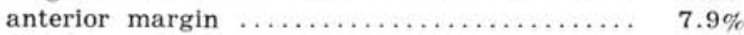

distal margin ....................... 3.7 \%

inner margin ......................... $5.2 \%$

fin tip to origin of caudal ................ $8.5 \%$

Pectoral fin:

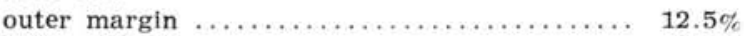

distal margin ........................... $9.3 \%$

inner margin ......................... $5.2 \%$

length of base ................. $7.8 \%$

breadth .............................. $9.5 \%$

Anal fin:

height $\ldots \ldots+2.7 \%$

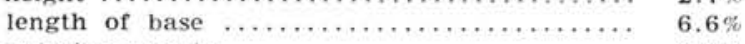

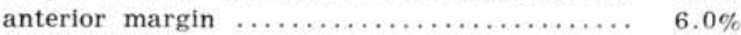

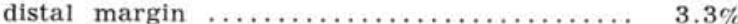

inner margin ...................... $1.6 \%$

fin tip to origin of caudal ................ $4.8 \%$

Caudal fin:

upper margin length ................. $34.3 \%$

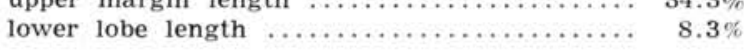

Caudal penduncle:

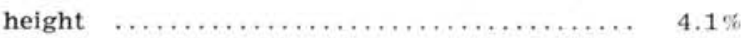

breadth ..................................

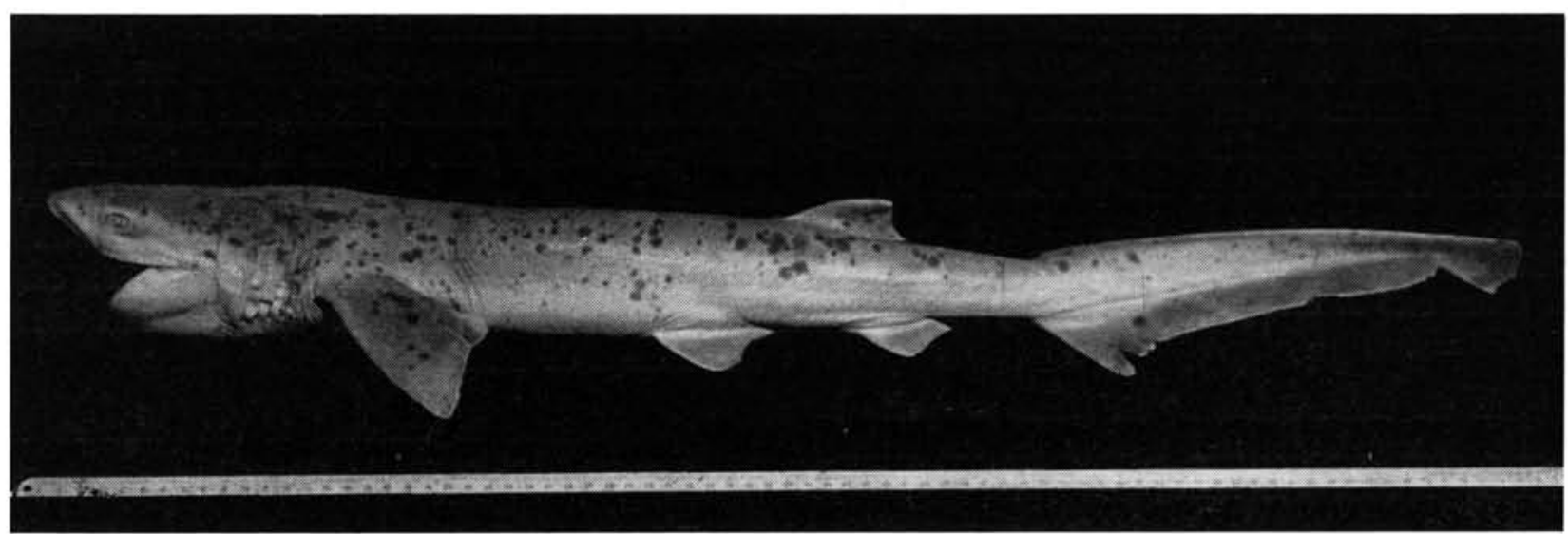

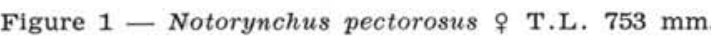


R E F E R E C E S

Bigelow, H. \& Schroeder, W.

1948. Sharks. In: Fishes of the Western North Atlantic. Mem. Sears FdnohL Res., vol. 1 , n. ${ }^{\circ}$, p. $59-576$.

Cadenat, J.

1950. Poissons de mer du Senegal. Dakar, I.F.A.N., 345 p.

CHen, J .

1963. A review of the sharks of Taiwan. Biol. Bull. Coll. Sci. Tunghai Univ., Ichthyol. ser., n. ${ }^{\circ}$, p. 1-102.

Fowler, H

1942. A list of the fishes known from the coast of Brazil. Archos Zool. Est. S Paulo, vol. 3, p. 115-184.

Garman, S

1913. The Plagiostomia (sharks, skates and rays). Mem. Mus. comp. Zool. Harv, vol. 36, p. $1-515$.

Garrick, J. \& SchUltz, L.

1963. A guide to the kinds of potentially dangerous sharks. In: Gilbert, P., ed. Sharks and survival. Boston, D.G. Heath, p. 3-60.
LAHille, F.

1928. Nota sobre unos peces elasmobranquios. An. Mus. nac. Hist. nat. "Bernardino Rivadavia”, vol. 34, n. ${ }^{\circ} 12$, p. 299-339.

MANDAY, D. G.

1968. Guia para los tiburones de aguas cubanas. Inst. oceanogr., Acad. Cienc. Cuba, ser. Oceanol., n. ${ }^{\circ}$ 1, p. 1-60

SADOWSKY, V

1967. Selachier aus dem Litoral von São Paulo, Brasilien. Beitr. neotrop. Fauna vol. 5, n. $^{\circ} 2$, p. $71-88$

1968. On the measurement of the total length of sharks. Zool. Anz., vol. 181, no. 3/4, p. 197-199.

SMITH, J.

1953 The sea fishes of Southern Africa. South Africa, Central News Agency, $564 \mathrm{p}$.

ToRTONESE, E.

1956. Leptocardia ciclostomata selachii. Bologna, Calderini, 334 p. (Fauna d'Italia, vol. 2) 